\title{
PHYSIOLOGICAL POTENTIAL OF BEAN SEEDS AS A FUNCTION OF POPULATION DENSITIES ON WINTER CROP SEASON, IN NORTHERN MINAS GERAIS
}

\author{
DESEMPENHO FISIOLÓGICO DE SEMENTES DE FEIJÃO-COMUM CULTIVADO \\ EM DIFERENTES DENSIDADES POPULACIONAIS NA SAFRA DE INVERNO, NO \\ NORTE DE MINAS GERAIS
}

\section{Hugo Tiago Ribeiro AMARO'; ${ }^{1}$ Andréia Márcia Santos de Souza DAVID ${ }^{2}$; Abner José de CARVALHO ${ }^{3}$; Ignacio ASPIAZÚ ${ }^{3}$; Izabel Costa SILVA NETA ${ }^{4}$; Marcos Gleidson Pereira dos SANTOS}

1. Engenheiro Agrônomo, Doutorando em Fitotecnia, Universidade Federal de Viçosa - UFV, Viçosa, MG, Brasil, htiagoamaro@yahoo.com.br; 2. Engenheira Agrônoma, Professora Doutora do Departamento de Ciências Agrárias, Universidade Estadual de Montes Claros - UNIMONTES, Janaúba, MG, Brasil; 3. Engenheiro Agrônomo, Professor Doutor do Departamento de Ciências Agrárias - UNIMONTES, Janaúba, MG, Brasil; 4. Engenheira Agrônoma, Doutoranda em Agronomia/Fitotecnia, Universidade Federal de Lavras - UFLA, Lavras, MG, Brasil; 5. Engenheiro Agrônomo, Doutorando em Fitotecnia - UFV, Viçosa, MG, Brasil.

\begin{abstract}
For adapting well to various soil and climatic conditions in Brazil and the tradition of high consumption, bean plays a key role in feeding the population. Despite the different environmental conditions, there are few specific cultivars for each planting season, particularly when aimed at the production of quality seeds. The objective of this study was to evaluate the physiological potential of bean seeds from five population densities, under the edafoclimatic conditions of Janaúba, northern Minas Gerais. The experiment was conducted on winter crop season, with planting in August 2011. The experimental design was a randomized block in 3 x 5 factorial, with four replicates. The treatments consisted of three cultivars of common bean with different growth types (Ouro Vermelho, Ouro Negro and BRSMG Madrepérola), and five densities $\left(100,200,300,400\right.$ and 500 thousand plants ha $\left.^{-1}\right)$. Seeds were evaluated for water content, germination and vigor (tests of first count, seedling emergence, emergence speed and accelerated aging). From the results, it can be concluded that the bean seeds of the cultivar Ouro Negro present superior physiological potential in relation to the cultivars Ouro Vermelho and BRSMG Madrepérola. Increasing the sowing density up to 300 thousand plants $\mathrm{ha}^{-1}$ is suitable for the production of bean seeds on winter crop season, representing a good alternative for cultivation in the region.
\end{abstract}

KEYWORDS: Phaseolus vulgaris L. Plant populations. Germination. Force.

\section{INTRODUCTION}

The common bean (Phaseolus vulgaris L.), by adapting well to various soil and climatic conditions in Brazil and by the high consumption tradition, plays a key role in the diet of the Brazilian population and in the demand for manpower (SENA et al., 2008). It is one of the major agricultural activities in the country, with its chain of production, processing and marketing generating employment and income, especially to lower income classes. Brazil stands out as the largest producer and consumer of beans. Considering the sown area and expected yield, the production of beans in the 2011/12 season should be 3.137 million tons (CONAB, 2012), with average yield estimated at $873 \mathrm{~kg} \mathrm{ha}^{-1}$. However, this value can be considered low, since in fields where a high technological level is used, values three times bigger have been obtained. Among the reasons pointed out for low yield in Brazil are extreme sensitivity of the crop to climatic variations, use of seeds with unknown origin, crop implantation in soils with high acidity and inappropriate use of population density in the production areas, particularly for semierect to erect bean cultivars (SHIMADA et al., 2000).

One of the first practices to be studied to adapt a species to a cultivation condition is the arrangement of plants, by the changes it provides in the microclimate, in the availability of light, nutrients, water, temperature and the interaction of plants with other biotic factors (JAUER et al., 2006). However, the best arrangement of plants depends on the intrinsic characteristics of the cultivar, such as size, growth habit and plant architecture, as well as the crop management system (BEZERRA et al., 2009), factors which will determine the ability for using available resources.

In addition, weather conditions represent another factor limiting production of bean cultivars with different growth habits, with effects also on the physiological quality of seeds. Therefore, planning 
the planting season must coincide with favorable climatic conditions in different growing seasons, since variations in temperature, relative humidity and precipitation can damage the seeds, harming its vigor.

Despite the different environmental conditions, there are few specific cultivars for each growing season, especially when aimed at the production of quality seeds. Thus, to enable the effective employment of these cultivars by farmers, it is necessary to test them in different edaphoclimatic regions, as well as adapt them to current production systems, typically developed for carioca bean cultivars, which predominantly exhibit growing habits II/III or III (ALVES et al., 2009). Hence, this study was conducted to evaluate the physiologic performance of common bean seeds grown in different population densities in winter crop season, in northern Minas Gerais.

\section{MATERIAL AND METHODS}

The experiment was conducted in winterspring season (winter crop season), planted in August 2011, in the municipality of Janaúba, northern Minas Gerais, with the following coordinates: $15^{\circ} 47^{\prime} 50^{\prime \prime} \mathrm{S}$ latitude and $43^{\circ} 18^{\prime} 31^{\prime \prime}$ $\mathrm{W}$ longitude, and altitude of $516 \mathrm{~m}$. The climate of the region according to Koppen's classification is "Aw" (tropical with dry winter), with average annual temperature and precipitation of $25^{\circ} \mathrm{C}$ and $900 \mathrm{~mm}$, respectively. Climatic data collected during the experiment are shown in Figure 1.

The soil of the experimental area was classified as an eutrophic Red Latosol (Eutrustox) (EMBRAPA, 2006), its main chemical characteristics are presented in Table 1.

Table 1. Chemical characterization of the soil samples of the experimental areas removed in the 0 to $20 \mathrm{~cm}$ depth. Janaúba, MG. 2012.

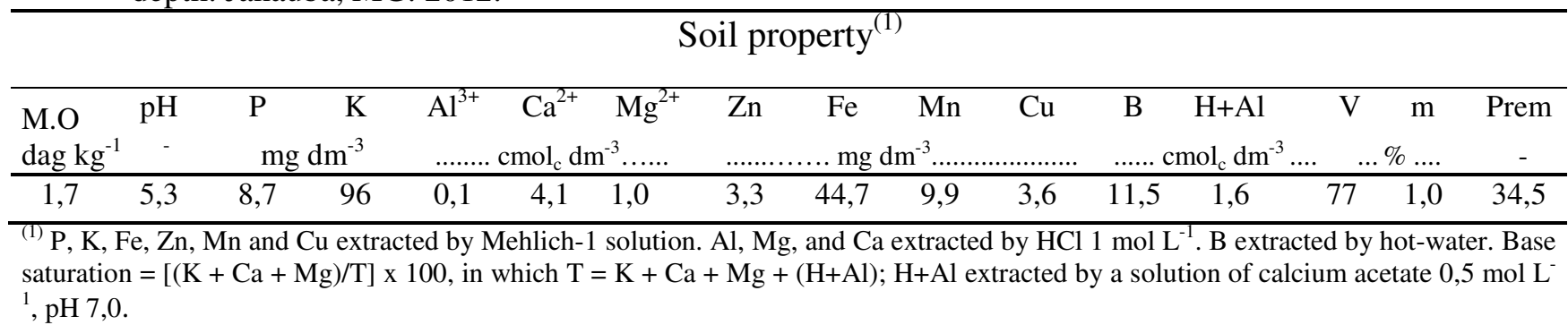

The experimental design was a randomized block in a 3 x 5 factorial scheme, with four replications. The treatments consisted of three cultivars of common bean with different types of growth (Ouro Vermelho, Ouro Negro and BRSMG Madrepérola), and five population densities (100, 200, 300, 400 and 500 thousand plants ha ${ }^{-1}$ ).

The cultivar Ouro Vermelho has grains of the type red commercial group, 80-90 days cycle, semiprostrated size and growth habit type II/III (indeterminate). On the other hand, the Ouro Negro presents grains of the black type commercial group, 80-100 days cycle, and growth habit type III (indeterminate) and prostrated size (PAULA JUNIOR et al., 2010). The BRSMG Madrepérola presents grains of the carioca commercial group, 80 days cycle, prostratedsize and, growth habit type III (indeterminate).

Each plot consisted of six rows with $5 \mathrm{~m}$ long, spaced $0.5 \mathrm{~m}$ apart, making a total area of 15 $\mathrm{m}^{2}$, being the useful area considered as the plants located in the fourth and fifth rows of each plot.

Soil tillage was conventional, consisting of one plowing and two harrowings, held before planting. Based on the results of chemical analyzes of samples collected in the experimental area, it was observed that there was no need for lime application. The beans fertilization was based on official recommendation for the State of Minas Gerais for Level 3 technology (CHAGAS et al., 1999) and consisted on the application of $375 \mathrm{~kg} \mathrm{ha}^{-}$ ${ }^{1}$ of the 04-30-10 formulation at planting, plus $40 \mathrm{~kg}$ $\mathrm{ha}^{-1}$ of nitrogen using urea as a source, applied to the soil in the form of a continuous bead during the V3V4 stage of the crop. In addition, it was carried out a foliar application of $40 \mathrm{~g} \mathrm{ha}^{-1}$ of molybdenum, using sodium molybdate as a source. Before sowing, the seeds were treated with mixtures of the fungicides carboxin and thiram at a dosage of $300 \mathrm{~mL} 100 \mathrm{~kg}^{-1}$ of seeds.

Sowing was done manually, using hand seeders, adopting the optimum sowing density with the aid of graduated wooden rulers marked for each sowing density predetermined by the treatments. At each point on the graduated ruler, two seeds were sown. After seedling emergence, thinning was done, leaving one plant per position.

Weed control was accomplished with the application of a tank mixture of the herbicides 
fomesafen and fluazifop-p-butyl at a dosage of 125 $\mathrm{g} \mathrm{ha}^{-1}, 25$ days after emergence. Complementary irrigation by conventional aspersion were used and constantly monitored, all phytosanitary measures being taken according to the necessity of the crop.

Plants belonging to the useful area of each plot were manually harvested, and then submitted to threshing for obtaining seeds. Due to differences in maturation periods that occurred between cultivars, the plots were harvested as soon as maturity was reached, which led to not harvesting all plots at a single time. The seeds were cleaned and dried, and then taken to the Seed Analysis Laboratory to evaluate the physiological quality, by means of the following tests and/or determinations:

Water content was determined as prescribed in the Rules for Seed Analysis - RAS (BRAZIL, 2009), using the oven method at $105 \pm 3{ }^{\circ} \mathrm{C}$ for 24 hours, with four replications of 50 seeds, being the results expressed in percentage.

For the germination test, four replicates of 50 seeds were distributed evenly over germination paper in roll form, moistened with distilled water at a ratio of 2.5 times its initial weight. The rolls were placed in a germination chamber preset at an alternated temperature of $25^{\circ} \mathrm{C}$ and constant light. Evaluations were made on the fifth and ninth days after installation of the test and the results expressed as percentage of normal seedlings, according to the RAS (BRAZIL, 2009).

The results of the first count test were obtained by the number of normal seedlings, determined during the first count of the germination test, ie, on the seventh day after installation (BRAZIL, 2009).

The seedling emergence test was conducted under laboratory conditions, and sowing carried out at a depth of $3 \mathrm{~cm}$ in plastic trays containing washed and sterilized sand as substrate, moistened with water equivalent to $60 \%$ of the retention capacity, and the moisture was maintained by daily irrigations (BRAZIL, 2009). Four replications of 50 seeds were used and the results were obtained by the number of normal seedlings emerged, determined during the ninth day after the installation of the test, being the results expressed in percentage.

The emergence speed index was conducted together with the seedling emergence test, noting daily, at the same time, the number of seedlings that showed visible hypocotyl. At the end of the test, the emergence speed index was calculated using the formula proposed by Maguire (1962).

For the accelerated aging test, 200 seeds per treatment were distributed on the surface of a metal screen fixed and suspended inside a plastic box containing $40 \mathrm{~mL}$ of distilled water, kept at $41{ }^{\circ} \mathrm{C}$ and $100 \%$ relative humidity for 72 hours inside a germinator (MARCOS FILHO, 1999). After this period, the seeds were removed from the chamber and germinated under the same conditions described for the germination test, being then determined the percentage of normal seedlings on the fifth day after installation of the test and the results expressed in percentage.

The data were not transformed because they met the assumptions of the normality and homogeneity tests, being subjected to analysis of variance. The effects of population densities were studied by regression analysis, choosing the appropriate models to represent them according to their biological behavior, to the significance of the model coefficients and to the coefficient of determination $\left(\mathrm{R}^{2}\right)$, and the effects of cultivars were studied by Tukey test at $5 \%(\mathrm{p}<0.05)$ significance level.

\section{RESULTS AND DISCUSSION}

Table 2 shows the analysis of variance of the data referring to the physiological quality of the seeds. It can be noted that, with the exception of the variable first germination count, there was significant effect of the variation source cultivar (CV) on the other evaluated characteristics. Sowing density (D) influenced significantly water content, thousand seeds mass and accelerated aging, while the double interaction CV x D was significant only for seed water content.

The development of the interaction CV x D, studying the effects of cultivars inside each sowing density, revealed that the seed water content showed different behavior from the studied cultivars, according to the data shown in Table 3. The seeds of the cultivars Ouro Negro and Madrepérola, which show prostrate size and growth habit type III, showed higher water contents in relation to the seeds from the cultivar Ouro Vermelho in most of the population densities. These results are certainly related to the size and growth habit of the cultivars.

In these cultivars, it is common to observe a higher contact of the pods with the soil in the period before harvest. This behavior, associated to the fact that harvest was performed in a period with frequent rainfall in the region (Figure 1), certainly contributed to the high water content values found in this work. 


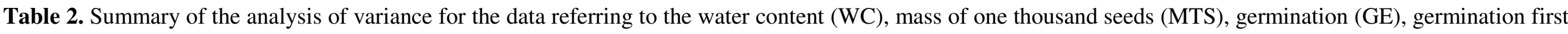
count (FC), seedling emergence (SE), emergence speed index (ESI) and accelerated aging (AE) of seeds of beans cultivars grown in five densities during the winter season, in northern Minas Gerais. Janaúba, MG. 2012.

\begin{tabular}{|c|c|c|c|c|c|c|c|c|}
\hline \multirow[b]{2}{*}{ Variation Sources } & \multirow[b]{2}{*}{ DF } & \multicolumn{6}{|c|}{ Mean Squares } & \multirow[b]{2}{*}{$\mathrm{AE}$} \\
\hline & & $\mathrm{WC}$ & MTS & GE & $\mathrm{FC}$ & $\mathrm{SE}$ & ESI & \\
\hline Cultivar (CV) & 2 & $125,44 * *$ & $4847,69 * *$ & $799,80 *$ & $304,06 \mathrm{~ns}$ & $375,26 * *$ & $68,84 * *$ & $1095,26 * *$ \\
\hline Density (D) & 4 & $12,40 *$ & $588,50 * *$ & $296,76 \mathrm{~ns}$ & $284,26 \mathrm{~ns}$ & $58,93 \mathrm{~ns}$ & $2,44 \mathrm{~ns}$ & $348,90 *$ \\
\hline$C V \times D$ & 8 & $9,18 *$ & $186,50 \mathrm{~ns}$ & $339,21 \mathrm{~ns}$ & $199,81 \mathrm{~ns}$ & $47,68 \mathrm{~ns}$ & $2,08 \mathrm{~ns}$ & $238,85 \mathrm{~ns}$ \\
\hline Block & 3 & 1,58 & 843,36 & 232,80 & 274,31 & 80,60 & 3,67 & 132,44 \\
\hline Residue & 42 & 3,29 & 130,10 & 221,80 & 212,69 & 71,21 & 2,66 & 117,15 \\
\hline $\mathrm{CV} \%$ & & 10,27 & 5,48 & 23,03 & 25,60 & 9,51 & 12,68 & 22,30 \\
\hline
\end{tabular}

${ }^{\mathrm{ns}}$ Non-significant; $(* *),(*)$ Significant at $1 \%$ e $5 \%$ probability by the $\mathrm{F}$ test, respectivelly.

Table 3. Water content (\%) of beans seeds of cultivars grown in five plant densities in winter season, in northern Minas Gerais. Janaúba, MG. 2012. Population densities (thousand plants ha ${ }^{-1}$ )

\begin{tabular}{|c|c|c|c|c|c|}
\hline Cultivars & 100 & 200 & 300 & 400 & 500 \\
\hline Ouro Vermelho & $17,8 \mathrm{AB}$ & $12,6 \mathrm{~B}$ & $15,8 \mathrm{~B}$ & $15,7 \mathrm{~B}$ & $15,4 \mathrm{~B}$ \\
\hline $\begin{array}{l}\text { Ouro Negro } \\
\text { Madrenérola }\end{array}$ & $\begin{array}{l}20,2 \mathrm{~A} \\
16,5 \mathrm{~B}\end{array}$ & $\begin{array}{l}19,0 \mathrm{~A} \\
180 \mathrm{~A}\end{array}$ & $\begin{array}{l}21,3 \mathrm{~A} \\
190 \mathrm{~A}\end{array}$ & $\begin{array}{l}21,4 \mathrm{~A} \\
195 \mathrm{~A}\end{array}$ & $\begin{array}{l}20,2 \mathrm{~A} \\
143 \mathrm{~B}\end{array}$ \\
\hline Means & 18,1 & 16,5 & 18,7 & 18,8 & 16,6 \\
\hline
\end{tabular}

Means followed by different letters in the column differ significantly by Tukey test at $5 \%$ probability. 

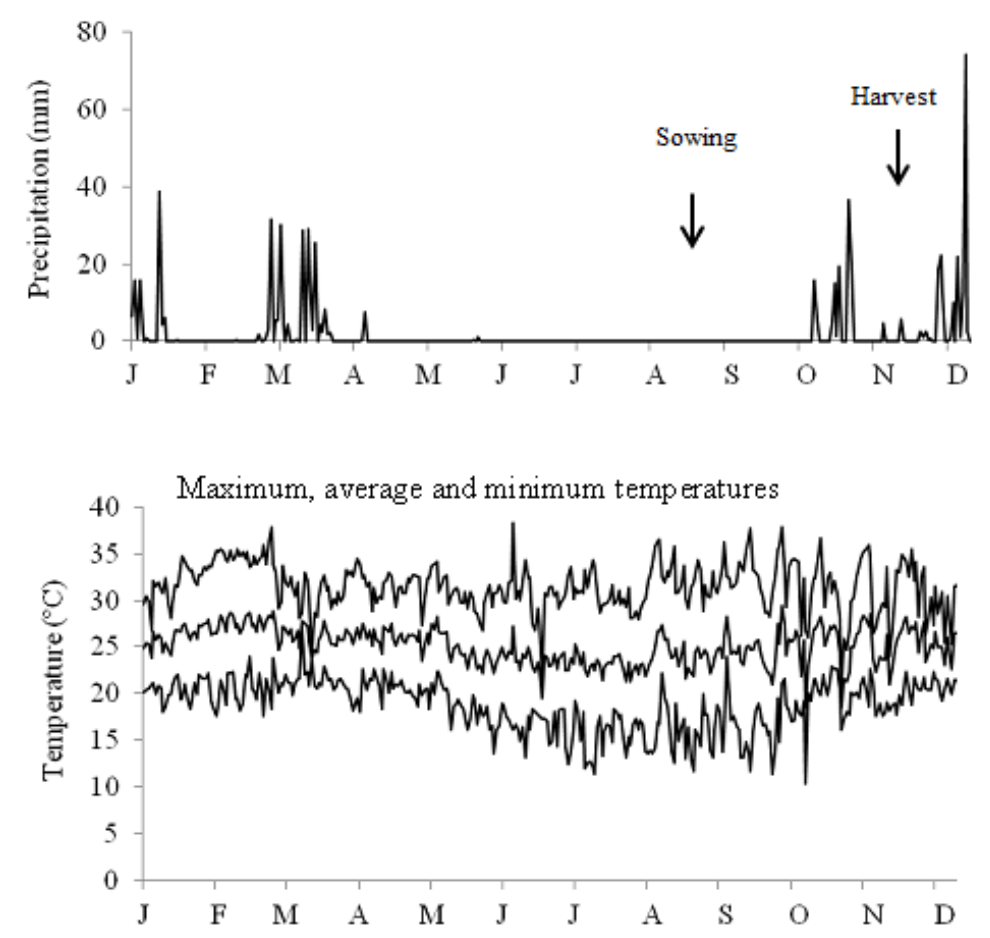

Figure 1. Daily variation of precipitation and temperature averages (maximum, average and minimum) during the year 2011. Data obtained from the Climatologic Station of the Minas Gerais Agricultural Research Agency (EPAMIG), northern regional unit of Minas Gerais, Nova Porteirinha, MG.

Sowing season must be adjusted in such a way that maturation and harvest of the seeds occur under mild temperature conditions, associated to lower precipitation indexes, according to França Neto et al (2007), factors which will determine harvesting seeds with ideal water content. On the contrary, harvest and subsequent storage of the beans seeds with water content superior to $13 \%$ can result in damages caused by changes in cell metabolism, with an increase in enzymatic and respiratory activities, allowing the development of fungi, with negative effects on seed quality.

Evaluating the effect of population densities in each cultivar, it can be observed significative difference only for the cultivar Madrepérola (Figure 2). Results of water content fitted to a quadratic model, in which increasing sowing densities caused increase in water content until the density of 300 thousand plants $\mathrm{ha}^{-1}$, reaching $19,3 \%$ of moisture.

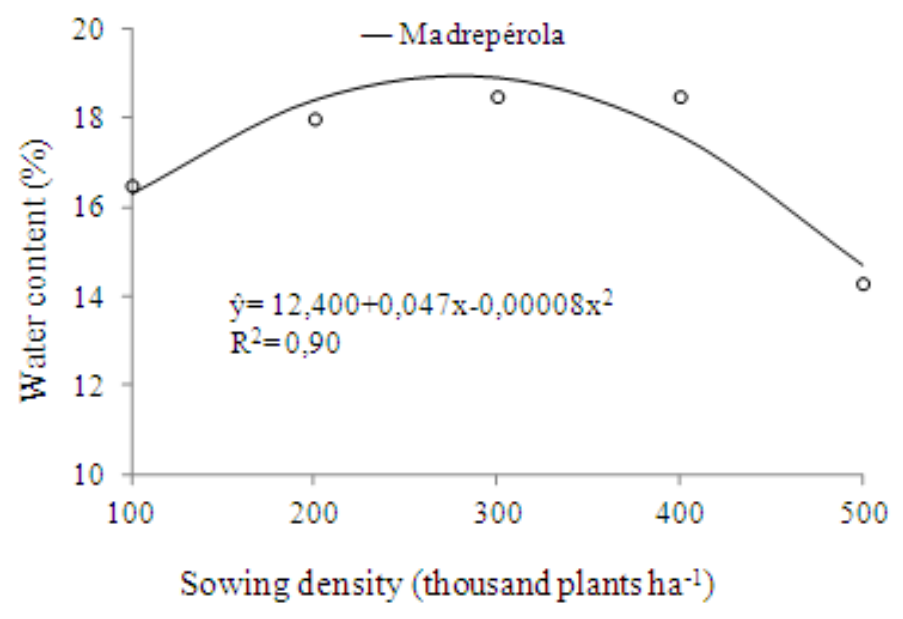

Figure 2. Water content (\%) of beans seeds of the cultivar Madrepérola, grown in five sowing densities in the winter season, in northern Minas Gerais. Janaúba, MG. 2012. 
The studied cultivars differed as for the mass of one thousand seeds (Table 4). The higher results were found in the seeds originated from the cultivars Ouro Vermelho and Madrepérola, showing results of 213,48 and 220,42 , respectively. In a general way, in can be highlighted that this characteristic is a feature of each cultivar, as inform Paula Junior et al (2010). However, the values reached in this work for the cultivars were inferior to the described by these authors, when compared to the mass of one hundred seeds. Probably, this result is explained by the more limitant climatic factors during the filling stage of the seeds (Figure 1). Carvalho et al (1998), verifying the effect of spacing and sowing season on the production of beans seeds, observed different behavior of the cultivars regarding the mass of one thousand seeds. The same authors found lower values when the cultivars were sown in the winter season, agreeing with the results of this work.

Table 4. Mass ( $\mathrm{g}$ ) of one thousand seeds of beans cultivars grown during winter season, in northern Minas Gerais. Janaúba, MG. 2012.

\begin{tabular}{lccc}
\hline \multirow{2}{*}{ Variable } & \multicolumn{3}{c}{ Cultivars } \\
\cline { 2 - 4 } & Ouro Vermelho & Ouro Negro & Madrepérola \\
\hline MTS & $213,48 \mathrm{a}$ & $190,66 \mathrm{~b}$ & $220,42 \mathrm{a}$ \\
\hline
\end{tabular}

Means followed by different letters in the line differ significantly by Tukey test at $5 \%$ probability.

The mass of one thousand seeds was influenced significantly by the sowing density, showing that this characteristic is affected by changes in plant population (Figure 3). Increasing sowing density caused increase in the mass of one thousand seeds until the density of 300 thousand plants $\mathrm{ha}^{-1}$, in which it was found the best result $(214,25 \mathrm{~g})$, with a reduction in the values from this point. Possibly this reduction is related to a higher competition for water, light and nutrients, caused by the increasing sowing densities.

The mass of one thousand seeds is a measure of quality used for different purposes, among them the comparison of the quality of different lots of seeds, as well as determining crops yields. In this sense, Carvalho e Nagakawa (2000) highlight that the bigger seeds have higher amount of reserves, being, therefore, the more vigorous.
Additionally, Jauer et al (2002) concluded that seed size did not affect the germination and vigor of bean cultivars TPS Bionobre, TPS Nobre e Xamego.

Although there is a great number of papers evaluating the effect of plant population on beans production, there is still no agreement as for the correct management of this parameter when evaluating the physiological potential of seeds. Several studies have been indicating contradictory results of mass of one thousand seeds in relation to plant population. Crusciol et al (2002) and Vazquez et al (2008) did not find variations in the mass of seeds in function of the evaluated plant populations. On the other hand, Tourino et al (2002), evaluating the effect of sowing density and uniformity on productivity and agronomical characteristics of soybeans, found decreases in the mass of seeds.

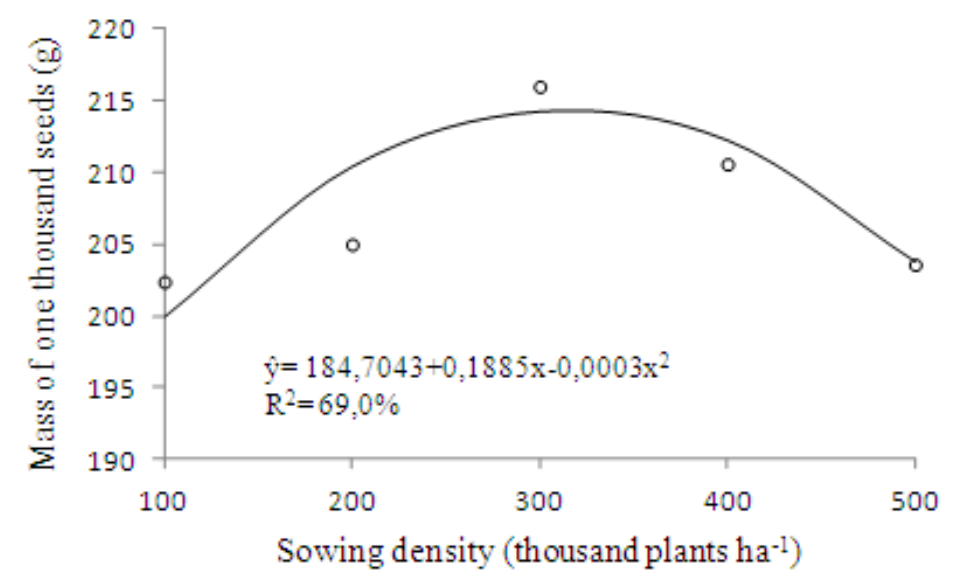

Figure 3. Mass ( $\mathrm{g}$ ) of one thousand seeds of the beans cultivars (means of the three cultivars), grown in five sowing densities during the winter season, in northern Minas Gerais. Janaúba, MG. 2012. 
In this sense, strategies to obtain higher responses of the crops to environmental conditions involve optimization of light interception by soil cover (SANTOS; FAGERIA, 2008), which can be obtained by managing plant population, a factor that should be very well elucidated when evaluating seed performance, as already mentioned.

Seeds germination showed differentiated behavior among the studied cultivars (Table 5). The seeds of the cultivar Ouro Negro presented higher performance in germination, while the seeds of the cultivars Ouro Vermelho and Madrepérola did not differ from each other. It can also be observed that only the seeds of the cultivar Ouro Negro showed germination superior to the standard considered as ideal for the commercialization of basic beans seeds. In general, the low values observed for seed germination percentage of the other studied cultivars is certainly associated to the climatic conditions verified during the period before seed harvest. The greater contact of plants, flowers and pods with the soil led to pod deterioration due to the occurrence of high temperatures and excessive rainfall, concentrated after physiological maturity of the plants (Figure 1).

Table 5. Average results, in percentage, of germination (GE) and first count (FC) of beans seeds grown during winter season, in northern Minas Gerais. Janaúba, MG. 2012.

\begin{tabular}{lccc}
\hline & \multicolumn{3}{c}{ Cultivars } \\
\cline { 2 - 4 } Variable & Ouro Vermelho & Ouro Negro & Madrepérola \\
\hline GE & $63 \mathrm{~b}$ & $76 \mathrm{a}$ & $60 \mathrm{~b}$ \\
FC & $56 \mathrm{a}$ & $61 \mathrm{a}$ & $54 \mathrm{a}$ \\
\hline
\end{tabular}

Means followed by different letters in the line differ significantly by Tukey test at $5 \%$ probability.

In soybeans seeds, França Neto et al (2007) report that exposing the seed to alternated cycles of elevated and low humidity before harvest, due to the occurrence of frequent rains or to daily fluctuations of high and low relative humidity of the air, will result in its deterioration by humidity, with direct consequences in seed quality.

It is important to highlight that to sow beans in the winter season can be justified by harvesting the grains in a period that there is a shortage of the product in the region. This way, new alternatives of sowing seasons are being researched, in function of the necessity of rotation with other crops and the possibility of a third "season" in only one agricultural year, also aiming seed production.

The seeds of the studied cultivars did not differ on the results of germination first count (Table 5). It can also be observed that the germination and germination first count of the evaluated cultivars did not suffer any effect of sowing densities. These results suggest that these characteristics can be little affected by changes in plant population, being more influenced by genetic characteristics and climatic conditions.

Regarding vigor (seedling emergence, emergence speed índex and accelerated aging), it can be noted a differentiated behavior among the analyzed cultivars (Table 6). In accordance with the germination results, the cultivar Ouro Negro showed higher physiological potential of the seeds, with $93 \%$ of seedling emergence, while the cultivars Ouro Vermelho and Madrepérola showed 88 and $85 \%$ of seedling emergence, respectively.

As it was expected, the seeds of the cultivar Ouro Negro showed superior performance for the results of emergence speed index, while for the other cultivars there was no statistically significant difference (Table 6).

Table 6. Average test results of seedling emergence (SE), emergence speed index (ESI) and accelerated aging (EA) of beans seeds grown during winter season, in northern Minas Gerais. Janaúba, MG. 2012.

\begin{tabular}{lccc}
\hline & \multicolumn{3}{c}{ Cultivars } \\
\cline { 2 - 4 } Variable & Ouro Vermelho & Ouro Negro & Madrepérola \\
\hline SE $(\%)$ & $88 \mathrm{~b}$ & $93 \mathrm{a}$ & $85 \mathrm{~b}$ \\
ESI & $12,2 \mathrm{~b}$ & $14,9 \mathrm{a}$ & $11,4 \mathrm{~b}$ \\
AE $(\%)$ & $48 \mathrm{ab}$ & $56 \mathrm{a}$ & $41 \mathrm{~b}$ \\
\hline
\end{tabular}

Means followed by different letters in the line differ significantly by Tukey test at $5 \%$ probability. 
Accelerated aging is recognized as one of the most important tests to evaluate seed vigor of several species, being able to provide information with a high consistency level. In this test, it is considered that seed lots with high vigor maintain their viability when submitted, over time periods, to severe conditions of temperature and relative air humidity (MARCOS FILHO, 2005).

In a similar way to the germination test, the low results observed in seed germination after accelerated aging is certainly related to the climatic conditions observed during the experiment (Figure 1). In this sense, Marcos Filho (2005) reports that at temperatures superior to $30{ }^{\circ} \mathrm{C}$ during the period of transferring dry matter from the plant to the seeds, which are related to the reduction in photosynthetic rate and photoassimilates translocation, usually siginificative after flowering in several species, such as the leguminous. The climatic conditions of each region, as humidity and temperature, vary with the seasons of the year. Thus, determining the sowing season, in a given region, means to expose the crop to the most diverse environment conditions during its development.

Figure 4 shows the regression equation and its coefficient of determination $\left(\mathrm{R}^{2}=0,85\right)$ for the accelerated aging in function of sowing densities. The results assumed a quadratic behavior, in which increasing sowing density caused an increase in germination until the density of 262.5 thousand plants $\mathrm{ha}^{-1}$, reaching the maximum germination percentage $(53 \%)$ after seed aging. From this density, there were reductions in the observed values, verifying $42 \%$ of germination after accelerated aging in the density of 500 thousand plants $\mathrm{ha}^{-1}$. The higher plant populations certainly led to a higher intraspecific competition and higher lodging caused by the high density of the plants in the field, and that probably hindered seed quality.

As reported, the studies evaluating the effects of plant populations on the physiological potential of seeds are rare and, in a certain way, contradictory. In their work, Vazquez et al (2008) concluded that variations in plant populations did not cause changes in the germination percentage and accelerated aging in soybeans seeds. On the other hand, Lazarini et al (2001) reported that the sowing density affected seed vigor when evaluated by the accelerated aging and the germination speed index.

It is important to point out that, in order to obtain higher responses to the technologies that may result in higher grain yields for the beans crop, using the adequate plant population is a crucial factor. Due to its great importance in the crop implantation phase, the best plant arrangement in the different production environments is a matter that still gets lots of interest in research, because, if executed in an inadequate way, it can compromise the subsequent phases of plant physiological development, with effects also on seed performance.

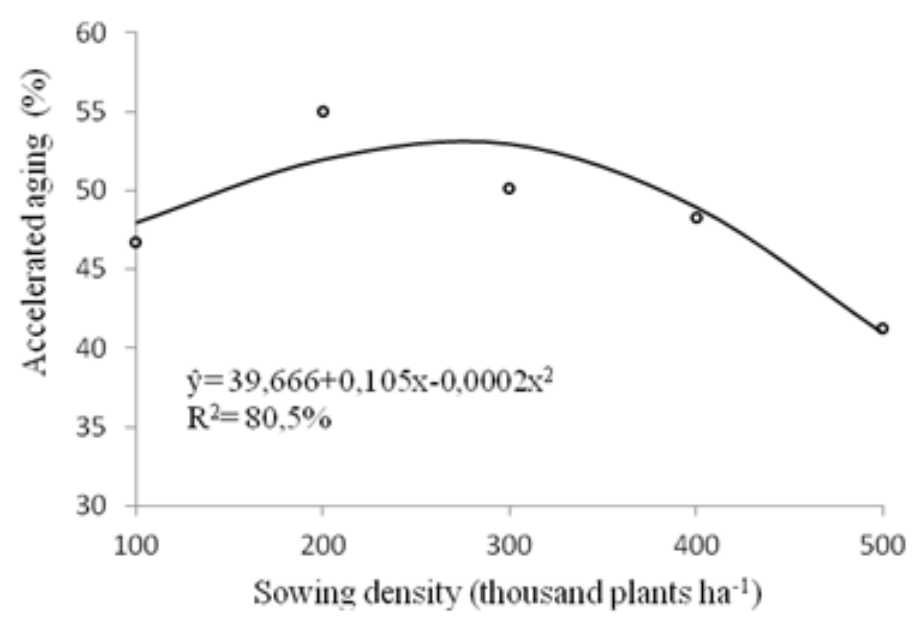

Figure 4. Accelerated aging (\%) of beans seeds cultivars (means of the three cultivars), grown during the winter season, in northern Minas Gerais. Janaúba, MG. 2012.

\section{CONCLUSIONS}

The beans seeds of the cultivar Ouro Negro present superior physiological potential in relation to the cultivars Ouro Vermelho and BRSMG Madrepérola.

Increasing sowing density up to 300 thousand plants ha ${ }^{-1}$ is adequate for producing beans 
seeds in the winter season, representing a good alternative for cultivation in the region.

\section{ACKNOWLEDGEMENTS}

To the Coordination for the Improvement of Higher Level Personnel (CAPES), by granting the scholarship to the first author of the paper; to the Minas Gerais Research Support Foundation (FAPEMIG) and the National Council for Scientific and Technological Development $(\mathrm{CNPq})$ for grants and financial support for the accomplishment of this work.

RESUMO: Por se adaptar bem às mais variadas condições edafoclimáticas do Brasil e pela alta tradição de consumo, o feijoeiro desempenha papel fundamental na alimentação da população brasileira. Apesar das condições ambientais distintas, existem poucas cultivares específicas para cada época de plantio, principalmente quando visa à produção de sementes de qualidade. Objetivou-se com este trabalho avaliar o desempenho fisiológico de sementes de feijão-comum cultivado em cinco densidades populacionais, nas condições edafoclimáticas de Janaúba, Norte de Minas Gerais. O experimento foi conduzido na safra de inverno, com plantio em agosto de 2011. O delineamento experimental utilizado foi em blocos casualizados, em esquema fatorial 3 x 5, com quatro repetições. Os tratamentos consistiram em três cultivares de feijão-comum de diferentes tipos de crescimento (Ouro Vermelho, Ouro Negro e BRSMG Madrepérola), e cinco densidades populacionais $\left(100,200,300,400\right.$ e 500 mil plantas ha $\left.^{-1}\right)$. As sementes foram avaliadas quanto ao teor de água, à germinação e ao vigor (testes de primeira contagem, emergência de plântulas, índice de velocidade de emergência e envelhecimento acelerado). Diante dos resultados, conclui-se que as sementes de feijão da cultivar Ouro Negro apresentam desempenho fisiológico superior em comparação com as cultivares Ouro Vermelho e BRSMG Madrepérola. O aumento da densidade de semeadura até 300 mil plantas ha ${ }^{-1}$ é adequado para a produção de sementes de feijão na safra de inverno, representando boa alternativa para o cultivo na região.

PALAVRAS-CHAVE: Phaseolus vulgaris L. População de plantas. Germinação. Vigor.

\section{REFERENCES}

ALVES, A. F.; ANDRADE, M. J. B.; RODRIGUES, J. R. M.; VIEIRA, N. M. B. Densidades populacionais para cultivares alternativas de feijoeiro no Norte de Minas Gerais. Ciência e Agrotecnologia, Lavras, v. 33, n. 6, p. 1495-1502, nov/dez. 2009.

BEZERRA, A. A. C.; TÁVORA, F. J. A. F.; FREIRE FILHO, F. R.; RIBEIRO, V. Q. Características de dossel e de rendimento em feijão-caupi ereto em diferentes densidades populacionais. Pesquisa Agropecuária Brasileira, Brasília, v. 44, n. 10, p. 1239-1245, out. 2009. http://dx.doi.org/10.1590/S0100204X2009001000005

BRASIL. Ministério da Agricultura, Pecuária e Abastecimento. Regras para Análise de Sementes. Brasília: DNDV/CLAV, 2009. 365 p.

CARVALHO, N. M.; NAKAGAWA, J. (Ed.). Sementes: ciência, tecnologia e produção. 4 ed. Jaboticabal: FUNEP, 2000. 588 p.

CARVALHO, M. A. C.; ARF, O.; SÁ, M. E. Efeito do espaçamento e épocas de semeadura sobre o desempenho do feijão. II. Qualidade fisiológica das sementes. Revista Brasileira de Sementes, v. 20, n.1, p. 202-208, 1998.

CHAGAS, J. M.; BRAGA, J. M.; VIEIRA, C.; SALGADO, L. T.; JUNQUEIRA NETO, A.; ARAÚJO, G. A. A.; ANDRADE, M. J. B.; LANA; R. M. Q.; RIBEIRO, A. C. Feijão. In: RIBEIRO, A. C.; GUIMARÃES, P. T. G.; ALVAREZ, V. V. H. (Ed.). Recomendações para o uso de corretivos e fertilizantes em Minas Gerais: $\mathbf{5}^{\mathbf{a}}$ aproximação. Viçosa, MG: Comissão de Fertilidade do Solo do Estado de Minas Gerais, 1999, p. 306-307.

CONAB - Companhia Nacional de Abastecimento. Acompanhamento de safra brasileira: grãos, oitavo levantamento, maio 2012/Companhia Nacional de Abastecimento - Brasília: Conab, 2012. 36 p. 
CRUSCIOL, C . A. C.; LAZARINI, E.; BUZO, C. L.; SÁ, M. E. Produção e qualidade fisiológica de sementes de soja avaliadas na semeadura de inverno. Scientia Agricola, Piracicaba, v. 59, n. 1, p. 75-96, jan./mar. 2002. EMPRESA BRASILEIRA DE PESQUISA AGROPECUÁRIA - EMBRAPA. Sistema Brasileiro de Classificação de Solos. 2. ed. Rio de Janeiro: Embrapa Solos, 2006. 306 p.

FRANÇA NETO, J. B.; KRZYZANOWSKI, F. C.; PÁDUA, G. P.; COSTA, N. P.; HENNING, A. A. Tecnologia da produção de semente de soja de alta qualidade - Série Sementes. Circular técnica, Londrina, 2007.

JAUER, A.; DUTRA, L. M. C.; ZABOT, L.; LUCCA FILHO, O. A.; UHRY, D.; LUDWIG, M. P.; FARIAS, J. R. Comportamento de cultivar Pérola de feijoeiro comum (Phaseolus vulgaris L.) em quatro densidades de semeadura na safrinha em Santa Maria - RS. Revista da FZVA, Uruguaiana, v. 13, n. 1, p. 12-23, 2006.

JAUER, A.; MENEZES, N. L.; GARCIA, D. C. Tamanho das sementes na qualidade fisiológica de cultivares de feijoeiro comum. Revista da FZVA, Uruguaiana, v. 9, n. 1, p. 65-72, 2002.

LAZARINI, E.; CRUSCIOL, C. A. C.; BUZO, C. L.; SÁ, M. E. Qualidade fisiológica de sementes de cultivares de soja semeadas em diferentes densidades no período de primavera e de outono após a colheita e o armazenamento. Revista Brasileira de Sementes, v. 23, n. 1, p. 68-75, 2001.

MAGUIRE, J. D. Speed of germination-aid in selection and evaluation for seedling emergence and vigor. Crop Science, Madison, v. 2, n.1 p. 176-177, 1962. http://dx.doi.org/10.2135/cropsci1962.0011183X000200020033x

MARCOS FILHO, J. Fisiologia de Sementes de Plantas Cultivadas. 1. ed. Piracicaba: FEALQ, 2005. 495 p.

MARCOS FILHO, J. Teste de envelhecimento acelerado. In: KRZYZANOWSKI, F. C.; VIEIRA, R. D.; FRANÇA NETO, J. B. (Ed.). Vigor de sementes: conceitos e testes. Londrina ABRATES, 1999. cap. 3, p.124.

PAULA JÚNIOR, T. J.; CARNEIRO, J. E. S.; VIEIRA, R. F.; ABREU, A. F. B.; RAMALHO, M. A. P.; PELOSO, M. J.; TEIXEIRA, H. Cultivares de feijão-comum para Minas Gerais. Belo Horizonte: EPAMIG, 2010, 39 p.

SANTOS, A. B.; FAGERIA, N. K. Características fisiológicas do feijoeiro em várzeas tropicais afetadas por doses e manejo de nitrogênio. Ciência e Agrotecnologia, Lavras, v. 32, n. 1, p. 23-31, jan/fev. 2008.

SENA, M. R.; ABREU, A. F. B.; RAMALHO, M. A. P.; BRUZI, A. T. Envolvimento de agricultores no processo seletivo de novas linhagens de feijoeiro. Ciência e Agrotecnologia, Lavras, v. 32, n. 2, p. 407- 412, mar./abr. 2008.

SHIMADA, M. M.; ARF, O.; SÁ, M. E. Componentes do rendimento e desenvolvimento do feijoeiro de porte ereto sob diferentes densidades populacionais. Bragantia, Campinas, v. 59, n. 2, p. 181-187, 2000.

http://dx.doi.org/10.1590/S0006-87052000000200009

TOURINO, M. C. C.; REZENDE, P. M.; SALVADOR, N. Espaçamento, densidade e uniformidade de semeadura na produtividade e características agronômicas da soja. Pesquisa Agropecuária Brasileira, Brasília, v. 37, n. 8, p. 1071-1077, ago. 2002.

VAZQUEZ, G. H.; CARVALHO, N. M.; BORBA, M. M. Z. Redução na população de plantas sobre a produtividade e a qualidade fisiológica da semente se soja. Revista Brasileira de Sementes, Londrina, v. 30, $\mathrm{n}$. 2, p. 01-011, 2008. 